\title{
Reproductive Biology of Weakly Electric Fish Eigenmannia trilineata López and Castello, 1966 (Teleostei, Sternopygidae)
}

\author{
Júlia Giora* and Clarice Bernhardt Fialho \\ Laboratório de Ictiologia; Departamento de Zoologia; Universidade Federal do Rio Grande do Sul; Av. Bento \\ Gonçalves, 9500; 90540-000; Porto Alegre - RS - Brasil
}

\begin{abstract}
This study described the reproductive biology of a population of the weakly electric fish Eigenmannia trilineata from southern Brazil, providing the information on the estimation of reproductive period, fecundity, spawning type, first maturation size, and analysis of gonadal morphology and histology of the species, relating these data to alimentary and abiotic characters. The species showed a relatively long reproductive period, a relative fecundity of 0.27 oocytes per mg of total weight and a parcelled spawning type. First maturation size estimated for the females was $80.5 \mathrm{~mm}$ and for the males $63.5 \mathrm{~mm}$ of total length. Sex ratio did not differ from 1:1 under a $X^{2}$ test $(\alpha=0.01)$ during all the sampled months. Sexual dimorphism was related to total length, and males had larger total length than females. The abiotic factors photoperiod and water conductivity presented significant correlations with female GSI, while male GSI presented a significant correlation only with photoperiod.
\end{abstract}

Key words: Reproductive biology, Gymnotiformes, Eigenmannia, abiotic factors, southern Brazil

\section{INTRODUCTION}

The order Gymnotiformes is restricted to Neotropical freshwaters, occurring from Guatemala to Argentina, and also on the Caribbean island of Trinidad (Mago-Leccia, 1976). These South American electric fishes are a very successful group, being found in all kinds of aquatic habitats, including river channels, floodplains, flooded forests, forest streams, waterfalls, swamps, coastal creeks and estuarine reaches (Crampton, 1998).

The Family Sternopygidae is known from the continental waters of all South American countries except Chile, ranging from the La Plata River of
Argentina to the Tuira River of Panama (Albert, 2001). The ecology and natural history of most sternopygid species are poorly understood (Albert, 2003).

The knowledge of the reproductive biology is fundamental for the maintenance and protection of natural stocks, cultivation for economic results and re-population of depleted areas (Agostinho and Júlio Jr, 1999). Nowadays, there are few studies on gymnotiform reproductive strategies. Barbieri and Barbieri (1982, 1983a, 1983b, 1984a, 1984b, 1985) presented data on fecundity, spawning type, reproduction dynamics, growth, first maturation size and gonadal histology of Gymnotus carapo of Lobo dam in São Paulo. Kirshbaum (1979)

\footnotetext{
* Author for correspondence: jugiora@ hotmail.com
} 
developed a study with Eigenmannia virescens in captivity proving the effect of four environmental factors (conductivity, $\mathrm{pH}$, water level, rain) on the species reproductive cycle definition. Kirschbaum and Schugardt (2003) provided information on reproductive strategies and developmental aspects in gymnotiform and mormirid fishes. Silva et al. (2003) studied the biogeography and breeding aspects of Brachyhypopomus pinnicaudatus from Uruguay.

The lack of knowledge on life history aspects, behaviour and ecology of gymnotiforms has been considered as an obstacle for a better understanding of this fish order. This study aimed to establish characteristics of the reproductive biology of an Eigenmannia trilineata population from Negra lagoon, Parque Estadual de Itapuã, Rio Grande do Sul state, Brazil, such as the reproductive period, spawning type and fecundity. It also aimed to test possible relationships between the environmental and feeding factors, and reproductive period determination. Besides that, the characteristics of the species population structure such as sex ratio, sexual dimorphism, individual recruitment time and first gonadal maturation size were examined. The male and female gonadal morphology was described in different stages of the reproductive cycle using histological analysis. Eigenmannia trilineata has been so far recognised as occurring in Paraná and Paraguay river basins in Brazil, Argentina, Paraguay and Uruguay (Albert, 2003), here this species occurrence in the Patos lagoon drainage, being reported .

\section{MATERIALS AND METHODS}

Parque Estadual de Itapuã, in the southern Brazil state of Rio Grande do Sul, is a state park with an area of $55.66 \mathrm{~km}^{2}$ and situated in the municipality of Viamão. It represents the last preserved ecosystem unit in the Porto Alegre's metropolitan region, and includes grassland, dunes, lakes, islands, beaches and forested hills along the margins of the Guaíba lake and Patos lagoon.

Negra lagoon covers $17.5 \mathrm{~km}^{2}$ and is separated from the Patos lagoon by sand dunes almost completely covered with bushes and herbs. The Negra lagoon west margin, opposite to the Patos lagoon, consists of an area previously used to raise the cattle, with abandoned irrigation channels for rice cultivation and some areas of Eucaliptus plantation.

The sampling site was located in one of these abandoned rice irrigation channel flowing into Negra lagoon west margin $\left(30^{\circ} 21^{\prime} 35.5^{\prime \prime} \mathrm{S}\right.$ and $\left.50^{\circ} 58^{\prime} 34^{\prime \prime} \mathrm{W}\right)$. The water has low transparency due to the large amount of organic matter in suspension, low acidity, a muddy bottom and an average depth of $1 \mathrm{~m}$. There was a predominance of aquatic macrophytes, with E. trilineata often found in the root mats of Pistia stratiotis, Salvinia auriculata, and roots of Poligonum sp.

Specimens were collected monthly from June 2002 to May 2003. Fishes were sampled between 11:00 a.m. and 12:30 p.m. using a dip net under floating vegetation and an electric fish finder, an audio-amplifier connected to electrodes mounted on the end of a pole.

The specimens were fixed in the field in $10 \%$ formalin solution. Water and air temperatures, water conductivity, $\mathrm{pH}$ and dissolved $\mathrm{O}_{2}$, were recorded at the time of collection. Rainfall data were obtained from the Meteorology District of Porto Alegre. Sunrise and sunset times and photoperiod were obtained with the Skymap software, correlating dates of collection with collecting place coordinates.

In the laboratory, fishes were transferred to $70 \%$ ethanol and total length (Lt) in millimetre and total weight $(\mathrm{Wt})$ in grams were measured. Individuals were dissected to record liver (Wl), stomach (Ws) and gonad weight $(\mathrm{Wg})$ and to establish the gonadal maturation stage of the males and females. Voucher specimens were catalogued in the fish collection of the Departamento de Zoologia, Universidade Federal do Rio Grande do Sul, Porto Alegre, Brazil (UFRGS 5719 and UFRGS 6635).

To study the microscopic characterization of gonadal maturation stages, some male and female gonads were selected for the histological analysis. These gonads were dehydrated and included in paraffin or historesin, and sectioned at three to five $\mu \mathrm{m}$ in a Leica microtome, model RM 2145. Sections were stained with Hematoxylin and Eosin or Toluidin blue.

Stomach repletion index (RI), hepatosomatic index (HsI), and gonadossomatic index (GSI) were estimated following the formula adapted from Santos (1978). These index represent the percentile organ weight related to fish total weight: $\mathrm{RI}=\mathrm{Ws} \times 100 / \mathrm{Wt}$; HsI = Wl $\times 100 / \mathrm{Wt}$; and GSI= 
Wg x 100/Wt where Ws corresponds to stomach weight, Wl to liver weight, $\mathrm{Wg}$ to gonad weight and $\mathrm{Wt}$ to total weight.

The reproductive period for the males and females was established through the analysis of the monthly variation of mean GSI values, as well as by the monthly variation of relative frequencies of the gonadal maturation stages. The multiple regression with analysis of variance (ANOVA) was applied to verify possible dependence between the abiotic (rainfall, photoperiod, temperature, conductivity, $\mathrm{pH}$ and dissolved $\mathrm{O}_{2}$ ) and feeding factors (RI and HsI), and the reproductive period (Zar, 1999).

The absolute fecundity was estimated counting all the vitellogenic oocytes present in the ovaries of 17 mature females. The relative fecundity was determined by the number of oocyte produced divided by the female weight (Adebisi, 1987).

For the determination of the spawning type, 41 gonads were selected representing all the gonad maturation stages. A sub-sample of 150 oocytes was removed from each selected gonad and the largest possible oocyte diameter was obtained with observation on a stereomicroscope with a millimetred ocular (Vazzoler, 1996).

The sex ratio was determined by the distribution of the male and female frequency during the sampled period. The $\chi^{2}$ test was applied to verify the existence of significant differences between the number of the male and female. The first gonadal maturation size of the males and females was estimated from the distribution of juvenile and adult relative frequencies for total length classes (Vazzoler, 1996). The obtained curve was adjusted according to the mathematical expression: $\mathrm{Fr}=1$ $\left(\mathrm{e}-\mathrm{aLt}^{\mathrm{b}}\right)$; where Fr corresponded to the relative frequency of adults, $e$ to the natural logarithm base, Lt to total length (mm), and $a$ and $b$ to the estimated constants related to curve adjustment. The first gonadal maturation size was considered as corresponding to a frequency of $0.5(50 \%)$ of the adult individuals.

The months when larvae (Nakatani et al., 2001) were observed were also recorded to determine the period of new individual breeding. The distribution of relative frequencies of males and females in different total length classes was analysed to observe size sexual dimorphism.

\section{RESULTS}

Overall 428 specimens of $E$. trilineata were collected: 209 males (total length from $35.29 \mathrm{~mm}$ $247.79 \mathrm{~mm}), 195$ females $(34.76 \mathrm{~mm}-170 \mathrm{~mm})$ and 24 larvae $(16.95 \mathrm{~mm}-32.02 \mathrm{~mm})$. From macroscopic and microscopic analysis of the gonads and according to the oogenesis and spermatogenesis phases described by Oliveira (2003), the following gonadal maturation stages were characterised for the females: maturing, mature, spawning and spent, and for the males: active and inactive. The same maturation stages could not be established for the males and females, since these did not show the same gonadal differentiation degree during the year. The larvae showed undifferentiated gonads, being considered in the immature stage.

Maturing female gonads appeared rigid and compact, with translucent oocytes at the starting stage and yellowish at the end, when the ovaries begin to occupy a larger part of the abdominal cavity. Histological (Fig. 1a) observations revealed oogonias, high numbers of store oocytes and small numbers of previtellogenic oocytes, which became more frequent towards the end of this stage when some vitellogenic oocytes were observed as well.

During the mature stage, the ovaries showed large oocytes with dark yellow coloration, occupying a large part of the abdominal cavity and it was possible to observe them inside the live fish abdomen through transparency. In the histological analysis (Fig 1b) high numbers of vitellogenic, previtellogenic and store oocytes could be seen, along with some oogonias.

The females considered in spawning stage had ovaries similar in size to others in the maturating stage, however, with a more flaccid consistency.

Histologically (Fig 1c), they showed vitellogenic and store oocytes, also presenting high numbers of empty follicles and atresic follicles.

In the spent stage, the females showed small and very flaccid ovaries, with translucent oocytes. The histological analysis (Fig 1d) showed store oocytes, empty and atresic follicles, and it was possible to observe the ovigerous lamellae distended.

The gonads of inactive males were small, slender, translucent or slightly whitish. In histological 
analysis (Fig 1e), high amount of spermatogonias and primary spermatocytes could be observed and smaller numbers of secondary spermatocytes and spermatids. At the end of this stage, small numbers of spermatozoa could be also observed.

The males in the active stage had thick and bulky gonads, with wavy edges and coloration varying from white to slightly yellowish. Histologically (Fig 1f), these gonads showed high amount of spermatozoa, spermatids, secundary spermatocytes, and it was also possible to observe primary spermatocytes and spermatogonias but always in smaller numbers.

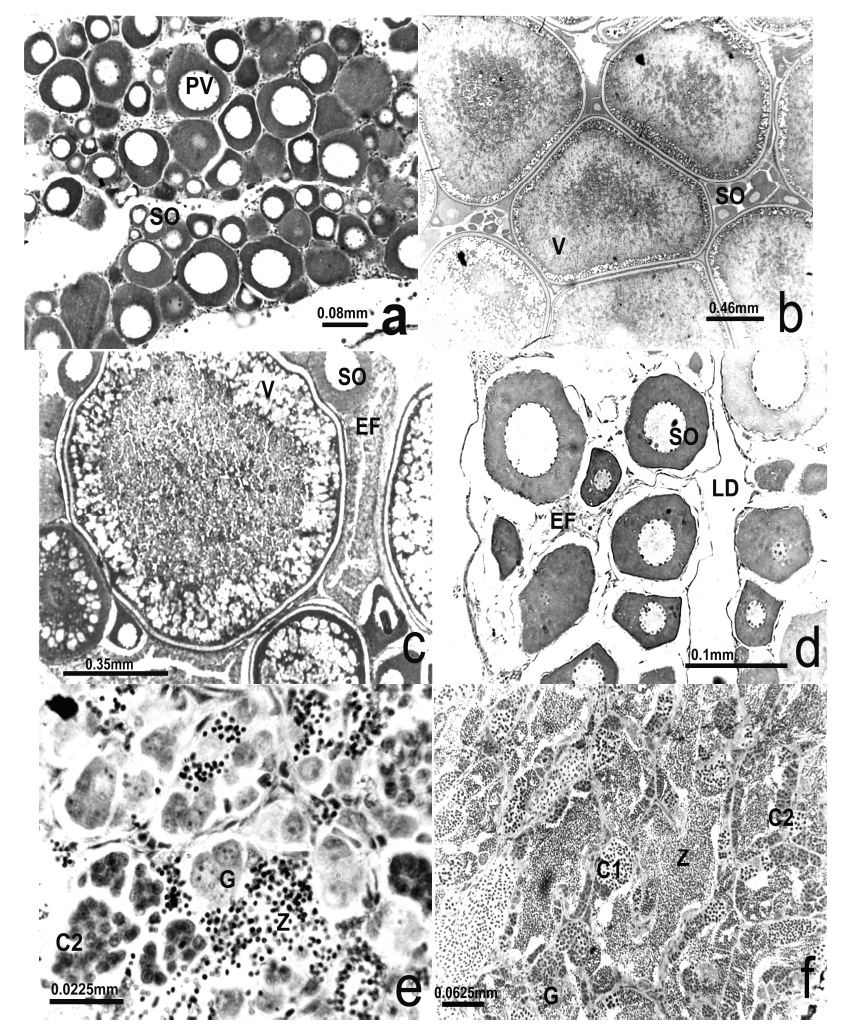

Figure 1 - Histological sections of E. trilineata ovaries and testis in different gonadal maturation stages. a: Maturing (female); b: Mature (female); c: Spawning (female); d: Spent (female); e: Inactive (male); f: Active (male). SO: store oocytes; PV: previtellogenic oocytes; V: vitellogenic oocytes; EF: empty follicle; LD: ovigerous lamellae distended; G: spermatogonias; C1: primary spermatocytes; C2: secundary spermatocytes; T: spermatids; Z: spermatozoas.

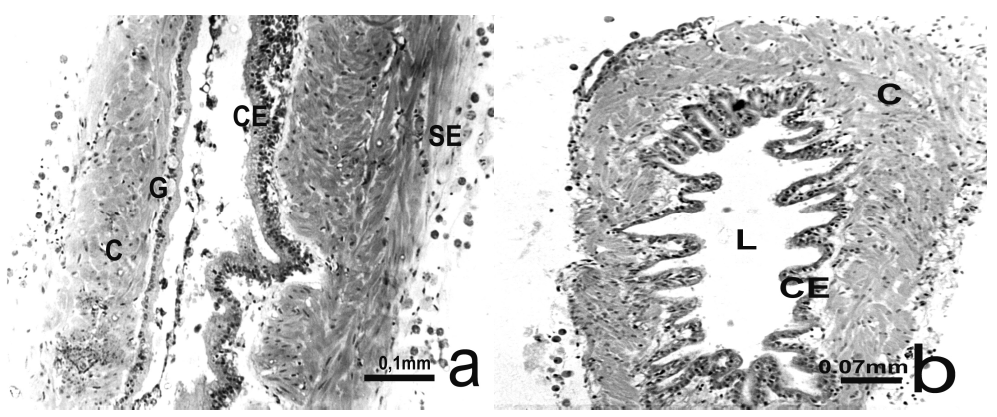

Figure 2 - Histological sections of E. trilineata gonoduct. a: sagittal section; b: transversal section. $\mathrm{SE}$ : squamous epithelial tissue; $\mathrm{CE}$ : cubic epithelial tissue; $\mathrm{C}$ : compact connective tissue; G: glandular tissue; L: gonoduct light. 
A structure defined as a gonoduct was found next to the male and female gonads in all the gonadal maturation stages. Histologically (Fig. 2a-b), this structure was constituted by the cubic epithelial tissue and glandular tissue. Some females were found spawning using this structure.

The estimated reproductive period lasted from October 2002 to February 2003, with the GSI peak occurring in November 2002 (Fig. 3) for the males and in October 2002 for the females (Fig. 3). Fig. 4 shows a high frequency of the mature females from October 2002 to February 2003, confirming the GSI data. The females in spawning stage were found from November 2002 to February 2003, in spent stage from November 2002 to April 2003, and in maturing stage during all the months of the year. Active males were very frequent during all the sampled year (Fig. 4).
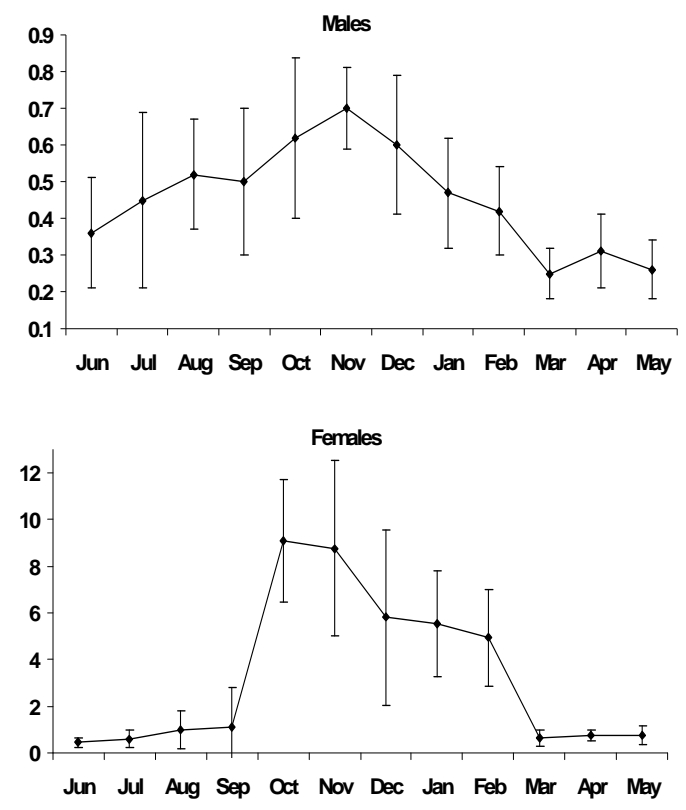

Figure 3 - Monthly variation of mean gonadossomatic index (GSI) for E. trilineata males and females from June/2002 to May/2003. Vertical bars represent the standard deviation.
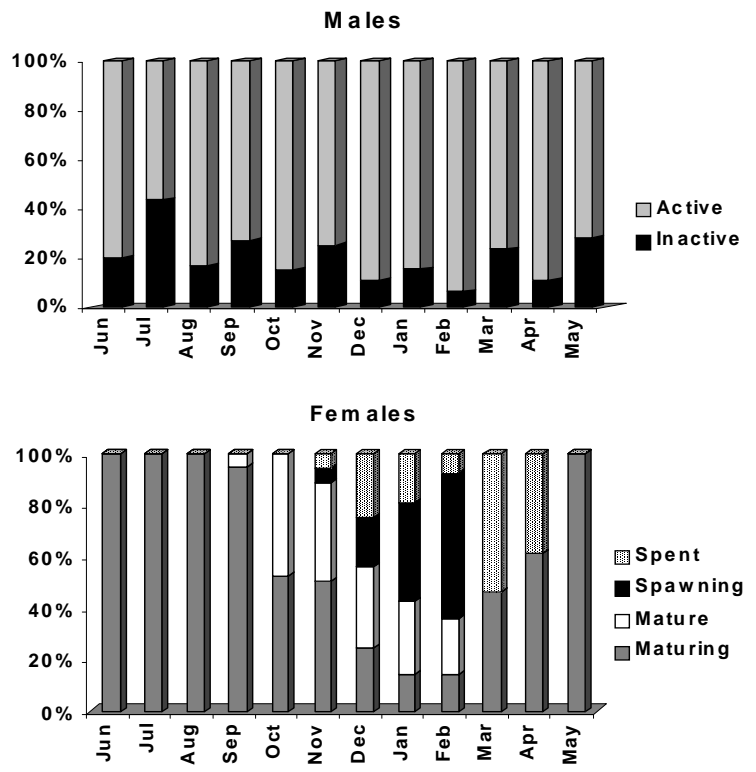

Figure 4 - Monthly variation of the gonadal maturation stage frequency of E. trilineata males and females. 
A significant dependence of the monthly data for repletion (RI) and hepatossomatic (HsI) index to GSI of the males $(\mathrm{F}=2.149$ and $\mathrm{t}=1.951 ; \mathrm{F}=1.282$ and $\mathrm{t}=-1.690)$ and females $(\mathrm{F}=0.992$ and $\mathrm{t}=$ $1.062 ; \mathrm{F}=1.668$ and $\mathrm{t}=0.620)$ could not be studied under an analysis of variance (Anova) of the multiple regression. Between the male and female GSI and the abiotic factors, a significant dependence was found for photoperiod in the males $(\mathrm{F}=12.944 ; \mathrm{t}=3.598)$ and for photoperiod $(\mathrm{F}=35.676 ; \mathrm{t}=2.261)$ and water conductivity $(\mathrm{F}=$ 51.982; $\mathrm{t}=-3.958)$ in the females. Monthly data for rainfall, photoperiod, water temperature, $\mathrm{pH}$, dissolved oxygen and conductivity are summarised in Table 1.

Table 1 - Monthly variation of the rainfall $(\mathrm{mm})$, photoperiod $(\mathrm{min})$, water temperature $\left({ }^{\circ} \mathrm{C}\right), \mathrm{pH}$, dissolved oxygen (mg/l) and conductivity $(\mu \mathrm{s} / \mathrm{cm})$ values in Negra lagoon.

\begin{tabular}{lcccccc}
\hline & Temperature & Dissolved $\mathbf{O}_{\mathbf{2}}$ & Conductivity & Ph & Rainfall & Photoperiod \\
\hline Jun & 13.3 & 6.02 & 52.8 & 5.78 & 178.8 & 613 \\
Jul & 14.6 & 5 & 59.9 & 5.95 & 186.6 & 629 \\
Aug & 25.2 & 5 & 49.3 & 6.12 & 154.3 & 682 \\
Sep & 18.3 & 7.5 & 47.2 & 6.38 & 167.8 & 733 \\
Oct & 20.7 & 7.05 & 10 & 7.16 & 8.75 & 796 \\
Nov & 20.7 & 6.61 & 12 & 7.19 & 58.75 & 835 \\
Dec & 23.3 & 5.0 & 28.2 & 9.15 & 68.2 & 857 \\
Jan & 25.2 & 3.47 & 28.8 & 6.69 & 65.45 & 815 \\
Feb & 25.5 & 4.43 & 36.3 & 6.76 & 99.6 & 770 \\
Mar & 22.2 & 4.43 & 46.5 & 7.3 & 108.2 & 732 \\
Apr & 19.9 & 2.42 & 45.4 & 6.54 & 88.9 & 679 \\
May & 18.7 & 0.4 & 49.7 & 6.16 & 46 & 637 \\
\hline
\end{tabular}

The absolute fecundity had an average value of 1196.06 oocytes (ranging from 744 to 2217 oocytes) for the females with total length from 12.99 to $17.07 \mathrm{~cm}$ (Table 2). The average relative fecundity was estimated as 0.27 oocytes per $\mathrm{mg}$ total weight (Table 2).

The analysis of the absolute frequency distribution of vitellogenic oocyte diameter conformed to that of a species with parcelled spawning (Fig. 5). There was a high frequency of store oocytes that matures in the next reproductive period, followed by oocyte shares in the successive maturation stages, which were eliminated at different times in the reproductive period. The first gonadal maturation size (Fig. 6) was estimated for the females as $80.5 \mathrm{~mm}$ and for the males as $63.5 \mathrm{~mm}$.
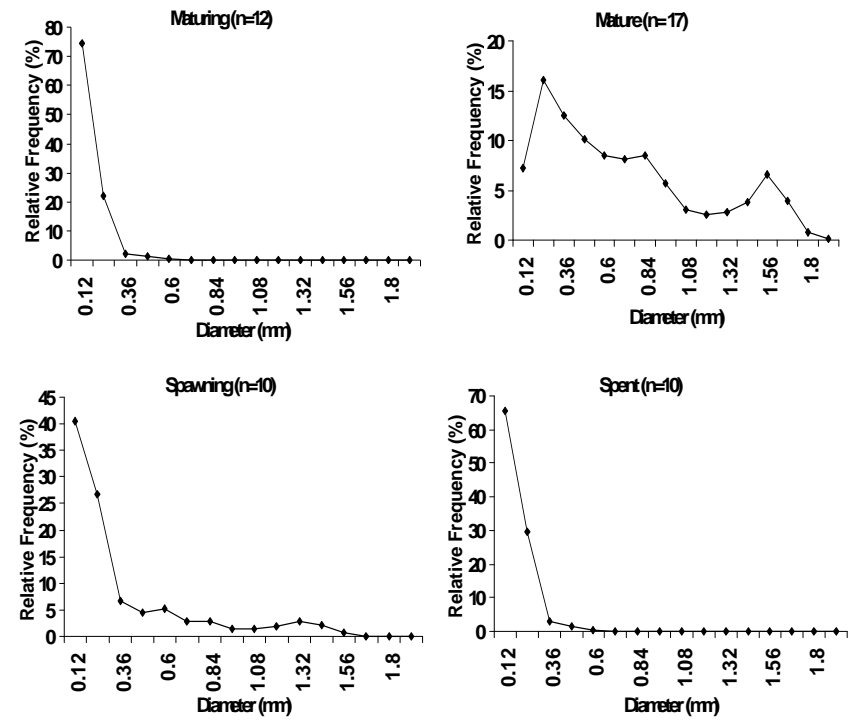

Figure 5 - Relative frequency distribution of oocyte diameters during the E. trilineata oocyte development process. 
Table 2 - Total length (Lt), total weight (Wt), gonadossomatic index (GSI), absolute fecundity (AF) and relative fecundity (RF) of 17 E. trilineata females.

\begin{tabular}{llllll}
\hline Lt & Wt & GST & AF & RF \\
\hline 129.99 & 2.5351 & 12.81 & 828 & 0.33 \\
132.33 & 3.2397 & 10.82 & 1145 & 0.35 \\
132.41 & 3.6416 & 12.47 & 1010 & 0.28 \\
134.01 & 3.0364 & 9.08 & 744 & 0.25 \\
135.15 & 3.6162 & 11.69 & 918 & 0.25 \\
136.12 & 5.0916 & 9.69 & 1301 & 0.26 \\
137.5 & 4.4509 & 10.47 & 1006 & 0.23 \\
138.69 & 4.0582 & 8.78 & 937 & 0.23 \\
& 138.7 & 5.2528 & 11.07 & 1328 & 0.25 \\
& 144.4 & 4.1141 & 8.87 & 950 & 0.23 \\
& 146.26 & 4.4734 & 10.05 & 1112 & 0.25 \\
147.29 & 4.3820 & 8.66 & 1501 & 0.34 \\
& 148.54 & 4.5234 & 9.94 & 1024 & 0.23 \\
\hline Averages & 4.9783 & 12.24 & 1346 & 0.27 \\
\hline
\end{tabular}
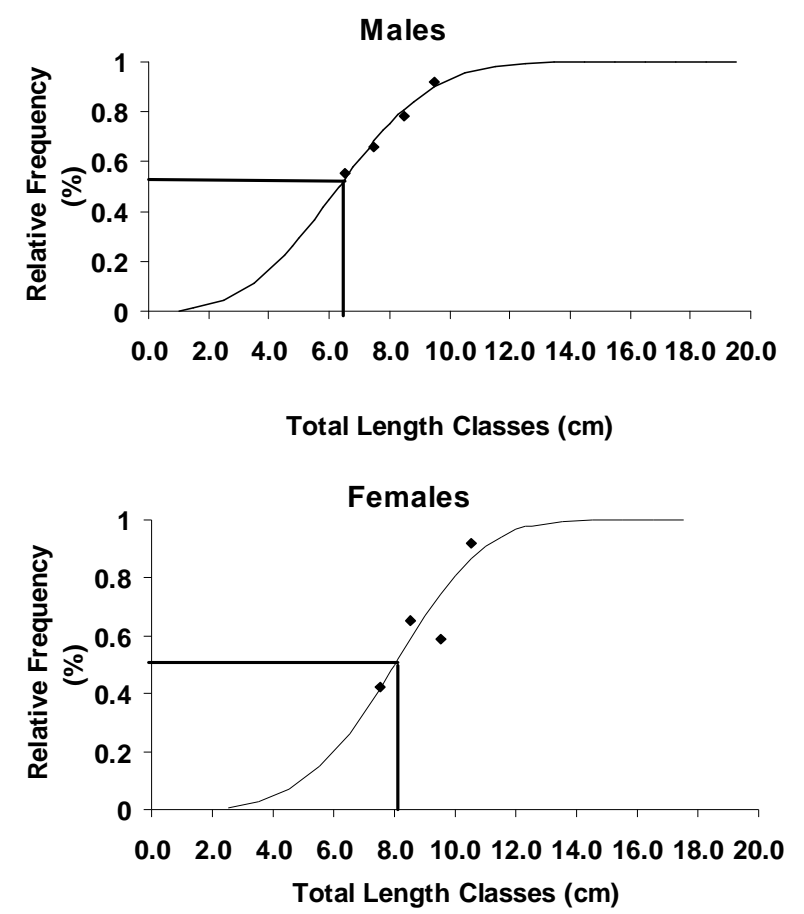

Figure 6 - Distribution of E. trilineata male and female relative frequencies for total length classes. The lines show the point at which $50 \%$ of the individuals are considered adults.

The $\chi^{2}$ test result $(\alpha<0.01)$ demonstrated a sex ratio of 1:1 in the studied population during all the sampled months. The time of new individual breeding was estimated as beginning in December 2002 and lasting until March 2003, these being the months when larvae were collected. There was size sexual dimorphism for total body length (Fig. 7 ), the males being longer than the females. The larger male reached $247.8 \mathrm{~mm}$ and the larger female $170.7 \mathrm{~mm}$. 


\section{DISCUSSION}

The elaboration of a gonadal maturation scale is fundamental for understanding a species biological and reproductive behaviour during the year and along its life cycle. According to Vazzoler (1996), this scale must be simple and appropriate to the focus species, whereas very detailed scales may lead to great mistakes and generalizations.

The microscopic classification of gonadal maturation stages is a time- and effort-consuming technique; however, it is precise because it can reveal the reproductive dynamics, considering specific phases of oocyte maturation (Dias et al., 1998).

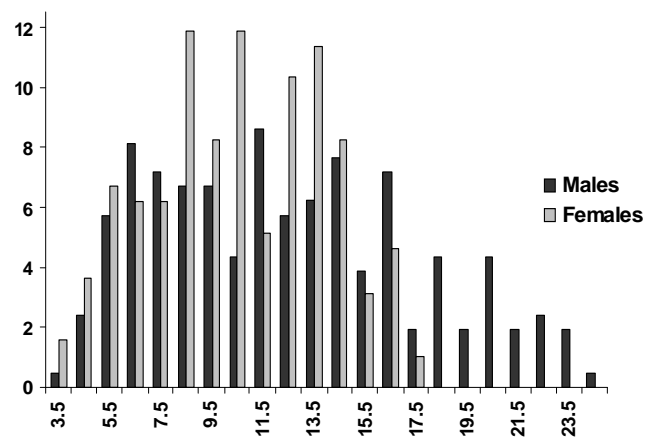

Figure7 - Relative frequency distribution of E. trilineata males and females for total length classes.

The macroscopic analysis gives immediate results, although taking into consideration the subjective characters, which are dependent on gonad and exemplars conservation processes leading to the classification and evaluation mistakes. Therefore, an association of both the macroscopic and microscopic classification techniques as in here may guarantee a more correct determination of male and female gonadal maturation stages.

Barbieri and Barbieri (1985) established five gonadal maturation stages for Gymnotus carapo females, one more than those here defined for $E$. trilineata. This extra stage is called the immature stage. For the males of the same species, Barbieri and Barbieri (1984a) established four maturation stages: immature, maturing, mature and spent. However, they did not detect large variations in $G$. carapo testis size and coloration during the reproductive cycle, observing spermatogenesis occurring throughout the year, only more intense in the species reproduction time. The existence of a continuous spermatogenesis as one of the main criteria to define the active and inactive stages for the male gonads was also observed in the histologycal analysis for E. trilineata. The males were found in inactive stage just for a short period of their lives. After reaching the first gonadal maturation, their gonads did not regress, remaining active in every length class during all the year.

The existence of a gonoduct in fishes has been studied in species with internal fecundation (Evans et al., 2003) or insemination (Munoz, Casadevall and Bonet, 1999) where this structure has an important role in sperm transference. Rasotto and Shapiro (1998) identified the presence of a gonoduct in the males and females of the coral reef species, Thalassoma bifasciatum, which would allow control of the liberated gamete amount in each reproductive event. There is no information about this structure for gymnotiforms; hence more studies are needed for the definition of its reproductive function.

Determination of the reproductive period is fundamental to the establishment of other aspects of species biology as well as its population dynamics. E. trilineata showed a seasonally differentiated reproductive period, occurring from October to February. This period corresponded to the southern hemisphere spring and summer, and could be considered a long reproductive season. According to Nikolsky (1963), the tropical and subtropical species are characterised by long reproductive periods in addition to eliminating 
more than one oocyte share during the reproductive season.

Many times, the reproductive processes present rhythms controlled by internal "biological clocks" and stimulated by environmental factors (Redding and Patiño, 1993). Barbieri and Barbieri (1983a) established the reproductive period of Lobo dam (SP) G. carapo as occurring from October to December, relating this period to the increase in temperature, precipitation, dissolved oxygen and photoperiod. Silva et al. (2003) have found sexually mature adults of Brachyhyроротиs pinnicaudatus from Uruguay from November to January, coinciding with high water temperatures.

Kirschbaum (1979), in captivity experiments, concluded that the abiotic factors influenced the $E$. virescens reproductive cycle, conductivity and $\mathrm{pH}$ reduction and water level along with rain amount increases leading to gonadal maturation, while the inverse process would lead to its regression. It was also found that conductivity was a determinant factor for gonadal development, which could be related to the gymnotiform fish electrossensorial capacity. Kirschbaum and Schugardt (2003) stated that gonadal maturation of Apteronotus leptorhynchus and Rhamphichthys sp. could be provoked by a decrease in conductivity and increase in water level while in Gymnotus carapo, it could occur only by a decrease in conductivity.

For the E. trilineata studied population, decreases in water conductivity were important to the definition of the reproductive period, since a negative correlation between the female GSI and variation of the monthly conductivity was found. This result was in agreement with the data described by Kirschbaum (1979).

Even though the coincidence between the reproductive time and the hottest period of the year has been recognised, there was no significant correlation between the GSI variation and water temperature. The monthly accumulated pluviometric precipitation, the dissolved oxygen percentage and the $\mathrm{pH}$ also did not present significant correlations with the GSI and, consequently, with the male and female reproductive periods.

The reproductive seasonality in the fishes of temperate environments, where longer rainfall periods are not definite, is mainly related to the temperature, photoperiod and food availability (McKayne, 1984; Payne, 1986). However, in tropical environments, the temperature and photoperiod variation are quite small, and then rainfall and habitat availability become the factors responsible for the seasonality in the rivers, streams and lagoons (Kramer, 1978; Welcomme, 1979; Goulding, 1980). The south region of Brazil presents a subtropical climate and many studies in this region (Azevedo et al., 2000; Lampert, 2003; Oliveira, 2003) revealed an association between the reproductive period and photoperiod. This tendency was also observed in the studied population, the established reproductive period occurring in the year time in which day length was increasing.

Among several other factors, fecundity depends on the coelomatic cavity capacity of lodge ripe oocytes and of the oocytes size (Vazzoler, 1996). Besides that, some characteristics such as parental care, spawning type, migration and fecundation type can interfere in the species fecundity, considering that the species offering fecundation and survival guarantee for the eggs and larvae usually show reduced fecundity values (Vazzoler and Menezes, 1992). The studied population probably has parental care given the detected larval agglomeration under the vegetation along with an adult male found in the sampling site from December 2002 to March 2003.

According to Crampton and Hopkins (2005) for Gymnotus species in the Amazon basin, these agglomerations corresponded to the larval nests which were protected by an adult male until they reached a certain size and disperse. This could explain the low fecundity found for E. trilineata during the sampled period. However, the shortage of studies about the gymnotiform reproduction did not allow a better discussion and comparison of the results.

Barbieri and Barbieri (1982) evaluated G. carapo average absolute fecundity at 2192 oocytes in the first sampled year, with female total length varying from $255 \mathrm{~mm}$ to $460 \mathrm{~mm}$, and 1791 oocytes in the second year, with female variation from $231 \mathrm{~mm}$ to $435 \mathrm{~mm}$. Relative fecundity data for the species were not presented rendering comparisons difficult.

Fecundity can also vary with female size, increasing with growth and being more related with individual length than with age (Vazzoler, 1996). This relation between fecundity and length can be observed in the studied population, since larger females had higher absolute fecundity values than females with smaller length.

The definition of a parcelled spawning for $E$. trilineata from the analysis of the frequency 
distribution of oocyte diameter was confirmed with gonadal histological observation, because the existence of a spawning stage in the females is characteristic of the species with parcelled spawning (Vazzoler, 1996). According to Nikolsky (1969), species with parcelled spawning are better adapted to unfavourable environmental conditions, and could solve problems of competition for spawning sites between the females of the same population. Moreover, multiple spawnings in the same reproductive period could result in a larger annual reproductive effort than that reached in a single spawn (Burt et al., 1988). This could also guarantee larger larval survival rates, permitting different spawning larvae to reach the planctophagous stage at different moments, and that way reducing the food competition. Parcelled spawnings were also reported by Barbieri and Barbieri (1982) for $G$. carapo, Alves-Gomes (pers. com.) for Eigenmannia sp., Kirschbaum (1979) for E. virescens and Kirschbaum and Schugardt (2003) for many species of gymnotiforms. Kirschbaum and Schugardt (2003) stated that all the available data indicated gymnotiforms to be fractional spawners.

Change in growth rates during the life cycle, often decreasing with increases in the age and after maturation, but they could vary with the diet changes (Lowe-McConnell, 1999). The information on first maturation size and average total length in which all individuals of the population would be able to participate actively in the reproductive process provides an indication of the species maturation process speed (Vazzoler, 1981). The males of E. trilineata had a faster maturation process than the females, being able to participate in the reproductive period from 63.5 $\mathrm{mm}$ long, while the females only from $80.5 \mathrm{~mm}$. However, Barbieri and Barbieri (1983b) found for G. carapo a much higher female first maturation size $(248 \mathrm{~mm})$ but this was not estimated for the males of this species.

Most fish natural populations have a 1:1 sex ratio, but when one of the sexes has some particular advantage, a tendency towards the production of a greater number of this sex can ensue (Reay, 1989). The studied species did not show a predominance of one of the sexes, having a 1:1 sex ratio during all the sampled months.
The sexual dimorphism observed in this $E$. trilineata population was also observed by Kirschbaum (1979) in E. virescens, where the largest male reached $330 \mathrm{~mm}$ and the largest female just $200 \mathrm{~mm}$. Since the sampled males showed a smaller first maturation size than the females, and reached a larger total length, it could be concluded that the males were in larger number participating in the reproductive period, in spite of the observed sex ratio. This strategy could have been adopted to guarantee the fecundation of all oocytes, increasing the population reproductive success.

\section{ACKNOWLEDGEMENTS}

We are grateful to Luiz R. Malabarba for comments on the manuscript and to the colleagues of the Laboratório de Ictiologia for their help during field work. To Capes for the scholarships given to senior author, and $\mathrm{CNPq}$ for financial support (proc. 464545/00-5; 476821/2003-7).

\section{RESUMO}

Este trabalho descreve a biologia reprodutiva de uma população do peixe elétrico Eigenmannia trilineata do Sul do Brasil. São apresentadas informações a respeito do período reprodutivo, fecundidade, tipo de desova, tamanho de primeira maturação, morfologia e histologia das gônadas da espécie, relacionando estes dados a caracteres alimentares e abióticos. A espécie apresentou período reprodutivo relativamente longo, com fecundidade relativa de 0,27 ovócito por miligrama do peso da fêmea e desova do tipo parcelada. O tamanho de primeira maturação gonadal estimado para fêmeas foi $80,5 \mathrm{~mm}$ e para machos, $63,5 \mathrm{~mm}$ de comprimento total. A proporção sexual, testada pelo teste $X^{2}(\alpha=0.01)$, foi de 1:1 durante todos os meses amostrados; dimorfismo sexual relacionado ao comprimento total foi detectado, possuindo os machos um maior comprimento total. Dos fatores abióticos testados, fotoperíodo e condutividade da água mostraram correlação significativa com o IGS das fêmeas, enquanto somente fotoperíodo apresentou-se relacionado ao IGS dos machos. 


\section{REFERENCES}

Adebisi, A. A. (1987), The relationships between fecundities, gonadossomatics indices and egg sizes of some fishes of Ogun River, Nigéria. Arch. Hydrobiol., 111 (1), 151-156.

Agostinho, A. A. and Júlio Jr, H. F. (1999), Peixes da bacia do alto Rio Paraná. In- Estudos ecológicos de comunidades de peixes tropicais, ed. R. H. LoweMcConnell. Edusp, São Paulo, pp. 374-400.

Albert, J. S. (2001). Species diversity and phylogenetic systematics of American knifefishes (Gymnotiformes, Teleostei). Misc. Publ. Mus. Zool. Univ. Mic.,. 190, 1-129.

Albert, J. S. (2003), Family Sternopygidae. In- Check list of the freshwater fishes of South and Central América, eds. R. E. Reis, S. O. Kullander, C. J. Jr. Ferraris. Edipucrs, Porto Alegre, pp. 487-491.

Alves-Gomes, J. A. (1997), Informações preliminares sobre a bio-ecologia de peixes elétricos (Ordem Gymnotiformes) em Roraima. In- Homem, Ambiente e Ecologia no Estado de Roraima, eds. R. I. Barbosa, E. J. G. Ferreira, E. G. Castellón, INPA, Manaus, pp. 509-555.

Azevedo, M. A., Malabarba, L. R. and Fialho, C. B. (2000), Reproductive biology of the inseminated Glandulocaudine Diapoma speculiferum Cope (Actinopterygii: Characidae). Copeia, 2000 (4), 983989.

Barbieri, G. and Barbieri, M. C. (1982), Fecundidade e tipo de desova de Gymnotus carapo (Linnaeus, 1758), na represa do Lobo, Estado de São Paulo (Pisces, Gymnotidae). Spectrum: J. Bras. Ci., 2 (7), 25-29.

Barbieri, G. and Barbieri, M. C. (1983a), Dinâmica da reprodução de Gymnotus carapo na represa do Lobo, Estado de São Paulo. Influência de fatores abióticos. (Pisces, Gymnotidae). Trop. Ecology, 24 (2), 244259.

Barbieri, G. and Barbieri, M. C. (1983b), Growth and first sexual maturation size of Gymnotus carapo (Linnaeus, 1758) in the Lobo reservoir (state of São Paulo, Brazil) (pisces, gymnotidae). Rev. Hydrobiol. trop., 16 (2), 195-201.

Barbieri, M. C. and Barbieri, G. (1984a.), Reprodução de Gymnotus carapo (Linnaeus, 1758) na represa do Lobo (SP.). Morfologia e histologia de testículo. Variação sazonal. (Pisces, Gymnotidae). Rev. Brasil. Biol., 44 (2), 141-148.

Barbieri, G. and Barbieri, M. C. (1984b), Crescimento de Gymnotus carapo (Linnaeus, 1758) na represa do Lobo, Estado de São Paulo, pelo método da distribuição da freqüência de comprimento (Pisces, gymnotidae). Rev. Brasil. Biol., 44 (3), 239-246.
Barbieri, M. C. and Barbieri, G. (1985), Reprodução de Gymnotus carapo (Linnaeus, 1758) na represa do Lobo (SP.). Morfologia e histologia de ovário. Variação sazonal. (Teleostei, Gymnotidae). Rev. Brasil. Biol., 45 (1/2), 3-12.

Burt, A., Kramer, D. L., Nakatsuru, K. and Spry, C. (1988), The tempo of reproduction in Hyphessobrycon pulchripinnis (Characidae), with a discussion on the biology of 'multiple spawning' in fishes. Environ. Biol. Fish., 22 (1), 15-27.

Crampton, W.G.R. and Hopkins, C. D. (2005), Nesting and paternal care in the weakly electric fish Gymnotus (Gymnotiformes: Gymnotidae) with descriptions of larval and adult electric organ discharges of two species. Copeia, 2005 (1), 48-60.

Dias, J. F., Peres-Rios, E., Chaves, P. T. C. and RossiWongtschowski C. L. D. B. (1998), Análise macroscópica dos ovários de Teleósteos: Problemas de classificação e recomendações de procedimentos. Rev. Brasil. Zool., 15 (3), 775-782.

Dunlap, K. D. and Zakon, H. H. (1998), Behavioral actions of androgens and androgen receptor expression in the electrocommunication system of na electric fish, Eigenmannia virescens. Hormon. Behav., 34, 30-38.

Evans, J. P., Pilastro, A., Ramnarine, I. W. (2003), Sperm transfer through forced matings and its evolutionary implications in natural guppy (Poecilia reticulata) populations. Biol. J. Linn. Soc., 78 (4), 605-612.

Goulding, M. (1980), The fishes and the forest, explorations in Amazoniam natural history. University of California Press, Los Angeles.

Grosser, K. M. and Hahn, S. D. (1981), Ictiofauna da Lagoa Negra, Parque Estadual de Itapuã, município de Viamão, Rio Grande do Sul, Brasil. Iheringia, 59, 45-64.

Kirschbaum, F. (1979), Reproduction of the weakly electric fish Eigenmannia virescens (Rhamphichtyidae, Teleostei) in captivity. Behav. Ecol. Sociobiol., 4, 331-355.

Kirschbaum, F and Schugardt, C. (2002), Reproductive strategies and developmental aspects in mormyrid and gymnotiform fishes. J. Physiol., 96 (2002), $557-$ 566.

Kramer, D. L. (1978), Reproductive seasonality in the fishes of a tropical stream. Ecology, 59 (5), 976-985.

Kramer, B. (1983), Electrocommucication in fish: stimulus waveform-dependent responses in Eigenmannia (Gymnotiformes, Teleostei) - a model for intraspecific communication?. Verh. dt. Zool. Ges., 1983, 170.

Kramer, B. (1985), Jamming avoidance in the electric fish Eigenmannia: harmonic analysis of sexually dimorphic waves. J. exp. Biol., 119, 41-69. 
Lowe-McConnell R. H. (1999), Estudos ecológicos de comunidades de peixes tropicais. Edusp, São Paulo.

Lampert, V. R. (2003), Biologia reprodutiva de duas espécies do gênero Bryconamericus (Characidae: Tetragonopterinae) dos sistemas dos rios Jacuí $e$ Uruguai, RS. Mastrers Dissertation, Universidade Federal do Rio Grande do Sul, Porto Alegre, Brasil.

McKaye, K. R. (1984), Behavioral aspects of ciclids reproductive strategies: patterns of territoriality and brood defense in Central American substratum spawners and African mouth brooders. In- Fish reproduction: strategies and tatics, eds. G. W. Potts, R. J. Wooton. Academic Press, London, pp. 245-273.

Munoz, M., Casadevall, M. and Bonet, S. (1999), Annual reproductive cycle of Helicolenus dactilopterus dactilopterus (Teleostei: Scorpaeniformes) with special reference to the ovaries sperm storage. J. Mar. Biol. Ass. U. K., 79 (3), 521-529.

Nakatani, K., Agostinho, A. A., Baumgartner, G., Bialezki, A., Sanches, P. V., Makrakis, M. C. and Pavanelli, C. S. (2001), Ovos e larvas de peixes de água doce - Desenvolvimento e manual de identificação. Eduem, Maringá.

Nikolshy, G. V. (1963), The ecology of fishes. Academic Press, London.

Nikolsky, G. V. (1969), Theory of fish population dynamics. Oliver and Boyd Ltda, Edinburg.

Reay, P. J. (1989), Reproductive tatics: a non-event in aquaculture?. In- Fish reproduction: strategies and tatics, eds. G. W. Potts, M. N. Wootton. Academic Press, London, pp. 291-309.

Redding, M. and Patiño, R. (1993), Reproductive Physiology. In- The Physiology of Fishes, ed. D. H. Evans. CRC Press, Boca Raton, pp. 503-529.

Oliveira, C. L. C. (2003), Análise comparada de caracteres reprodutivos e da glândula branquial de duas espécies de Cheirodontinae (Teleostei: Characidae). Masters Dissertation, Universidade Federal do Rio Grande do Sul, Porto Alegre, Brasil.
Payne, A. I. (1986), The ecology of tropical lakes and rivers. John Wiley Press, New York.

Rasotto, M. B. and Shapiro, D. Y. (1998), Morphology of gonoducts and male genital papilla, in the bluehead wrasse: implications and correlates on the control of gamete release. J. Fish. Biol., 52, 716-725.

Santos, E. P. dos. (1978), Dinâmica de populações aplicada à pesca e piscicultura. Edusp, Sâo Paulo.

Silva, A., Quintana, L., Galeano, M. and Errandonea, P. (2003), Biogeography and breeding in Gymnotiformes from Uruguay. Environ. Biol. Fish., 66, 329-338.

Vazzoler, A. E. A. de M. (1981), Manual de métodos para estudos biológicos de populações de peixes. Reprodução e crescimento. CNPQ, Brasília.

Vazzoler, A. E. A. de M. (1996), Biologia da reprodução de peixes teleósteos: teoria e prática. Editora da Universidade, Maringá.

Vazzoler, A. E. A. de M. and Menezes, N. A. (1992), Síntese de conhecimentos sobre o comportamento reprodutivo dos Characiformes da América do Sul (Teleostei, Ostariophysi). Rev. Brasil. Biol., 52 (4), 627-640.

Welcomme, R. L. (1979), Fisheries ecology of floodplain rivers. Longman, Lodon.

Wootton, R. J. (1989). Introduction: tactics and strategies in fish reproduction. In- Fish reproduction: strategies and tatics, eds. G. W. Potts, M. N. Wootton. Academic Press, London, pp. 1-12.

Zar, J. H. (1999), Biostatistical analisis. Prentice-Hall, New Jersey.
Received: January 30, 2007; Revised: September 25, 2007; Accepted: June 13, 2008. 